\title{
ANALISIS KESESUAIAN KUALITAS TAHU YANG DIMINTA DAN KUALITAS TAHU YANG DITAWARKAN DI KOTA MATARAM
}

\author{
ANALYSIS OF QUALITY SUITABILITY OF DEMANDED \\ AND SUPPLIED TOFU IN MATARAM MUNICIPAL
}

Ni Ketut Sri Pujasai, Taslim Sjah, dan Halil

Program Studi Agribisnis Fakultas Pertanian Universitas Mataram

\begin{abstract}
ABSTRAK
Penelitian ini bertujuan untuk : (1) menganalisis kualitas tahu yang diminta oleh konsumen di Kota Mataram; (2) menganalisis kualitas tahu yang ditawarkan oleh produsen di Kota Mataram; dan (3) menganalisis kesesuaian kualitas tahu yang diminta oleh konsumen dan kualitas tahu yang ditawarkan oleh produsen di Kota Mataram.

Penelitian ini menggunakan metode deskriptif dan pengumpulan data primer dilakukan dengan teknik survei dan dilengkapi pengumpulan data sekunder. Unit analisis dalam penelitian ini adalah konsumen dan produsen tahu di Kota Mataram. Penelitian ini dilaksanakan di Kota Mataram. Dari 6 kecamatan di Kota Mataram ditetapkan 4 kecamatan sebagai daerah sampel penelitian konsumen yaitu Kecamatan Mataram, Sekarbela, Sandubaya dan Kecamatan Cakranegara dan 2 kecamatan sebagai daerah sampel penelitian produsen yaitu Kecamatan Sandubaya dan Kecamatan Sekarbela secara purposive sampling atas pertimbangan bahwa kecamatan tersebut memiliki jumlah konsumsi dan produksi tahu terbanyak dari 6 kecamatan lainnya. Jumlah responden konsumen ditentukkan secara "quota sampling" yakni 30 konsumen. Untuk menentukan responden konsumen di keempat kecamatan tersebut menggunakan teknik "accidental sampling". Jumlah sampel produsen tahu diambil secara "quota sampling" yakni 30 produsen. Selanjutnya jumlah responden produsen di masing-masing kecamatan dilakukan secara "quota sampling" (50\% produsen di Desa Abiantubuh dan 50\% produsen di Desa Kekalik Jaya). Untuk menentukan responden produsen di kedua kecamatan tersebut menggunakan teknik "accidental sampling".

Hasil penelitian menunjukkan bahwa : (1) Konsumen tahu di Kota Mataram meminta (mengkonsumsi) tahu dengan kualitas cukup empuk, berwarna cukup putih, dan sangat segar; (2) Produsen tahu di Kota Mataram menawarkan (memproduksi) tahu dengan kualitas cukup empuk, berwarna putih, dan sangat segar; (3) Terdapat kesesuaian antara tingkat keempukan, warna dan kesegaran tahu yang diminta oleh konsumen dan tahu yang ditawarkan oleh produsen di Kota Mataram.
\end{abstract}

Kata kunci: Kualitas, Permintaan, Penawaran, Kesesuaian. 


\begin{abstract}
The purposes of this research are to : (1) analyze the quality of tofu demanded by consumers in Mataram Municipal; (2) analyze the quality of tofu supplied by producers in Mataram Municipal; (3) analyze the suitability of the quality of tofu demanded by consumers and the quality of tofu suppied by producers in Mataram Municipal.

This study used descriptive methods and primary data collection is done by survey techniques and supplemented by secondary data collection. The units of analysis in this study were consumers and producers of tofu in Mataram Municipal. From 6 districts in Mataram Municipal, 4 districts were designated as consumer research sample areas, namely Mataram, Sekarbela, Sandubaya and Cakranegara, and 2 districts as producer research sample areas namely Sandubaya and Sekarbela, determined by purposive sampling based on the consideration that the districts had total consumption and most tofu production from 6 other districts. The number of consumer respondents determined by "quota sampling" ie 30 consumers. Consumer respondents in the four districts were determined by "Accidental Sampling" technique. As for the number of tofu producers, samples were taken by "quota sampling", i.e. 30 producers. Furthermore, the number of producer respondents in each district was allocated by "quota sampling" (50\% of producers in Abiantubuh Village and 50\% of producers in Kekalik Jaya Village). To determine producer respondents in the two districts, the "Accidental Sampling" technique was applied.

The results showed that: (1) Consumers of tofu in Mataram Municipaldemanded tofu with a quality that was quite tender, quite white in color, and very fresh; (2) Tofu producers in Mataram City supplied tofu with a fairly soft quality, white in color, and very fresh; (3) Therefore, the tofu quality demanded and suppleid in Mataram Municipal is suitable in the level of tenderness, color and freshness.
\end{abstract}

Keywords: Quality, Demand, Supply, Suitability

\title{
PENDAHULUAN
}

Pertanian adalah kegiatan pemanfaatan sumber daya hayati yang dilakukan manusia untuk menghasilkan bahan pangan, bahan baku industri, atau sumber energi, serta untuk mengelola lingkungan hidupnya (Wikipedia, 2010).

Sektor pertanian merupakan sektor strategis dalam pembangunan nasional. Peran sektor pertanian dalam memacu perekonomian dapat dilihat lebih luas terutama dalam konteks mendistribusikan hasil-hasil pembangunan kepada masyarakat di wilayah pedesaan (Soekartawi, 2002).

Agribisnis adalah bisnis berbasis usaha pertanian atau bidang lain yang mendukungnya, baik di sektor hulu maupun di hilir. Penyebutan "hulu" dan "hilir" 
mengacu pada pandangan pokok bahwa agribisnis bekerja pada rantai sektor pangan (food supply chain) (Wikipedia, 2013).

Dalam agribisnis dikenal dengan adanya sistem agribisnis. Sistem agribisnis merupakan totalitas atau kesatuan kinerja agribisnis yang terdiri atas subsistem agribisnis hulu, subsistem usahatani, subsistem pengolahan, subsistem pemasaran, dan subsistem penunjang (Yusuf, 2004).

Subsistem pengolahan hasil pertanian sangat diperlukan untuk hasil-hasil pertanian, karena kita tahu bersama bahwa sifat produk pertanian yang tidak tahan lama, harga yang merosot saat masa panen, dan lain sebagaianaya. Lingkup kegiatan subsistem pengolahan hasil tidak hanya aktivitas pengolahan sederhana di tingkat petani, tetapi menyangkut keseluruhan kegiatan mulai dari penanganan pasca panen produk pertanian sampai pada tingkat pengolahan lanjutan dengan maksud untuk menambah value added (nilai tambah) dari produksi primer tersebut. Dengan demikian proses pengupasan, pembersihan, pengekstraksian, penggilingan, pembekuan, pengeringan, dan peningkatan mutu (Saragih, 1997).

Tahu adalah makanan yang dibuat dari kacang kedelai, diolah dengan fermentasi dan diambil sarinya. Dengan kata lain, tahu merupakan dadih kedelai, yaitu susu kedelai yang dibuat menjadi kental (curd) kemudian dicetak dan dipres (Winarno, 1993).

Tahu memiliki kandungan gizi yang sangat banyak yaitu seperti energi, air, protein, lemak, karbohidrat, mineral, serat, kalsium, natrium, dan fosfor, zat besi, Vitamin A, dan Vitamin B. Tahu juga mengandung lebih banyak mineral yang berasal dari senyawa koagulan yang memadatkan sari kedelai. Disamping itu tahu juga dikenal luas memiliki isoflavon yang sangat tinggi. Isoflavon sendiri adalah antioksidan yang baik untuk menjaga tubuh dari berbagai masalah kesehatan tubuh (Sarwono \& Saragih, 2003).

Setelah mengetahui beraneka kandungan gizi yang ada di dalam tahu tersebut pada zaman modern ini semakin banyak produsen yang memproduksi tahu. Di Kota Mataram terdapat 304 unit usaha dengan menyerap tenaga kerja sebanyak 875 orang, seperti rincian pada Tabel 1.

Tabel 1. Rekapitulasi Sentra Agroindustri Tahu di Kota Mataram, 2019

\begin{tabular}{lclrc}
\hline No. & Nama Sentra & \multicolumn{1}{c}{ Desa/Kelurahan } & Unit & Tenaga Kerja (Orang) \\
\hline 1. & Tahu & Abian Tubuh Baru & 66 & 228 \\
2. & Tahu & Ampenan Utara & 6 & 19 \\
3. & Tahu & Kekalik Jaya & 227 & 609 \\
4. & Tahu & Pagutan Timur & 5 & 19 \\
\hline \multicolumn{5}{c}{ Jumlah } \\
\hline
\end{tabular}

Sumber : Dinas Perindustrian Provinsi NTB (2019, diolah)

Banyaknya produsen tahu sekarang ini, mengakibatkan berbagai macam kualitas tahu yang ada dari segi keempukan, warna, kesegaran, dan lain-lain. Berdasarkan uraian di atas, peneliti telah melakukan penelitian dengan judul "Analisis Kesesuaian Kualitas Tahu Yang Diminta dan Kualitas Tahu Yang Ditawarkan di Kota Mataram" dengan tujuan sebagai berikut : menganalisis kualitas tahu yang diminta oleh konsumen di Kota Mataram; menganalisis kualitas tahu yang ditawarkan oleh 
produsen di Kota Mataram; dan menganalisis kesesuaian kualitas tahu yang diminta oleh konsumen dan kualitas tahu yang ditawarkan oleh produsen di Kota Mataram.

\section{METODE PENELITIAN}

Metode yang digunakan dalam penelitian ini adalah metode deskriptif, sedangkan pengumpulan data dalam penelitian ini dilakukan dengan teknik survei. Unit analisis dalam penelitian ini adalah konsumen dan produsen tahu di Kota Mataram. Penelitian ini dilaksanakan di Kota Mataram. Dari 6 kecamatan di Kota Mataram ditetapkan 4 kecamatan sebagai daerah sampel penelitian konsumen yaitu Kecamatan Mataram, Sekarbela, Sandubaya dan Kecamatan Cakranegara dan 2 kecamatan sebagai daerah sampel penelitian produsen yaitu Kecamatan Sandubaya dan Kecamatan Sekarbela secara purposive sampling atas pertimbangan bahwa kecamatan tersebut memiliki jumlah konsumsi dan produksi tahu terbanyak dari 6 kecamatan lainnya. Jumlah responden konsumen ditentukkan secara quota sampling yakni 30 konsumen. Untuk menentukan responden konsumen di keempat kecamatan tersebut menggunakan teknik "accidental sampling" yaitu teknik penentuan sampel berdasarkan kebetulan, yaitu siapa saja yang secara kebetulan bertemu dengan peneliti dapat digunakan sebagai sampel, bila dipandang orang yang kebetulan ditemui itu cocok sebagai sumber data. Sedangkan untuk jumlah produsen tahu diambil sampel atau responden secara "quota sampling" yakni 30 produsen. Selanjutnya jumlah responden produsen di masing-masing kecamatan dilakukan secara "quota sampling" yaitu teknik penentuan sampel dari populasi yang mempunyai ciri-ciri tertentu sampai jumlah (jatah) yang dikehendaki yakni 50\% produsen di Desa Abiantubuh dan 50\% produsen di Desa Kekalik Jaya. Untuk menentukan responden produsen di kedua kecamatan tersebut menggunakan teknik "accidental sampling" yaitu teknik penentuan sampel berdasarkan kebetulan, yaitu siapa saja yang secara kebetulan bertemu dengan peneliti dapat digunakan sebagai sampel, bila dipandang orang yang kebetulan ditemui itu cocok sebagai sumber data. Jenis data dalam penelitian ini adalah data kualitatif dan kuantitatif. Sedangkan sumber data yang digunakan dalam penelitian ini berasal dari data primer dan data sekunder. Adapun variabel-variabel yang diukur dalam penelitian ini adalah keempukan, warna, dan kesegaran pada tahu. Data dianalisis menggunakan analisis deskriptif untuk kualitas tahu (tingkat keempukan, warna, dan kesegaran) dan kesesuiannya.

\section{HASIL DAN PEMBAHASAN}

\section{Analisis Kualitas Tahu yang Diminta Oleh Responden Konsumen di Kota Mataram}

Dalam penelitian ini peneliti mengukur tingkat kualitas tahu yang diminta di Kota Mataram dari segi tingkat keempukan, warna, dan kesegaran tahu. Dari hasil 
penelitian tingkat keempukan tahu yang diminta oleh responden konsumen tahu di Kota Mataram, 2020 dapat dilihat pada Tabel 2.

Tabel 2. Pengelompokan Tingkat Keempukan Tahu yang Diminta Oleh Responden Konsumen di Kota Mataram, 2020

\begin{tabular}{llcc}
\hline No. & Tingkat Keempukan & Jumlah (orang) & Persentase (\%) \\
\hline 1. & Sangat Tidak Empuk & 0 & 0 \\
2. & Tidak Empuk & 0 & 0 \\
3. & Cukup Empuk & 26 & 87 \\
4. & Empuk & 4 & 13 \\
5. & Sangat Empuk & 0 & 0 \\
\hline & $\quad$ Jumlah & 30 & 100
\end{tabular}

Sumber : Data primer diolah (2020)

Pada Tabel 2 dapat dilihat bahwa tingkat keempukan yang diminta oleh responden konsumen sebagian besar sebanyak 26 orang atau $87 \%$ pada tingkat cukup empuk. Sementara pada tingkat empuk sebanyak 4 orang atau $13 \%$.

Selain tingkat keempukan, tingkat warna tahu juga menjadi salah satu faktor dalam kualitas tahu yang diminta oleh responden konsumen. Tingkat warna tahu yang diminta oleh responden konsumen di Kota Mataram, 2020 dapat dilihat pada Tabel 3.

Tabel 3. Pengelompokan Tingkat Warna Tahu yang Diminta Oleh Responden Konsumen di Kota Mataram, 2020

\begin{tabular}{llcc}
\hline No. & Tingkat Warna & Jumlah (orang) & Persentase (\%) \\
\hline 1. & Sangat Tidak Putih & 0 & 0 \\
2. & Tidak Putih & 0 & 0 \\
3. & Cukup Putih & 22 & 73 \\
4. & Putih & 8 & 27 \\
5. & Sangat Putih & 0 & 0 \\
\hline & Jumlah & 30 & 100
\end{tabular}

Sumber : Data primer diolah (2020)

Pada Tabel 3 dapat dilihat bahwa tingkat warna tahu yang diminta oleh responden konsumen sebagian besar yaitu sebanyak 22 orang atau $73 \%$ pada tingkat cukup putih. Sementara pada tingkat putih sebanyak 8 orang atau $27 \%$.

Faktor terakhir yang mempengaruhi kualitas tahu yang diminta oleh responden konsumen adalah dari kesegaran tahu tersebut. Tingkat kesegaran tahu yang diminta oleh responden konsumen di Kota Mataram, 2020 dapat dilihat pada Tabel 4. 
Tabel 4. Pengelompokan Tingkat Kesegaran Tahu yang Diminta Oleh Responden Konsumen di Kota Mataram, 2020

\begin{tabular}{llcc}
\hline No. & \multicolumn{1}{c}{ Tingkat Kesegaran } & Jumlah (orang) & Persentase $(\%)$ \\
\hline 1. & Sangat Tidak Segar & 0 & 0 \\
2. & Tidak Segar & 0 & 0 \\
3. & Cukup Segar & 0 & 0 \\
4. & Segar & 0 & 0 \\
5. & Sangat Segar & 30 & 100 \\
\hline & $\quad$ Jumlah & 30 & 100
\end{tabular}

Sumber : Data primer diolah (2020)

Dari Tabel 4 dapat dilihat bahwa tingkat kesegaran yang diminta seluruh responden konsumen yaitu tahu dengan tingkat sangat segar. Responden konsumen memilih tahu dengan tingkat sangat segar ini dikarenakan responden kosumen menginginkan kandungan gizi pada tahu tidak berkurang. Tingkat sangat segar yang dimaksud disini adalah tahu yang baru selesai diproduksi langsung dipasarkan ke konsumen. Menurut responden konsumen tingkat kesegaran tahu ini diukur dari tidak adanya lendir, dan tidak berbau busuk pada tahu tersebut.

\section{Analisis Kualitas Tahu yang Ditawarkan Oleh Responden Produsen di Kota Mataram}

Dalam penelitian ini peneliti mengukur tingkat kualitas tahu yang ditawarkan oleh responden produsen di Kota Mataram dari segi tingkat keempukan, warna, dan kesegaran tahu. Dari hasil penelitian tingkat keempukan tahu yang ditawarkan oleh responden produsen tahu di Kota Mataram, 2020 dapat dilihat pada Tabel 5.

Tabel 5. Pengelompokan Tingkat Keempukan Tahu yang Ditawarkan Oleh Responden Produsen di Kota Mataram, 2020

\begin{tabular}{llcc}
\hline No. & Tingkat Keempukan & Jumlah (orang) & Persentase $(\%)$ \\
\hline 1. & Sangat Tidak Empuk & 0 & 0 \\
2. & Tidak Empuk & 0 & 0 \\
3. & Cukup Empuk & 25 & 84 \\
4. & Empuk & 4 & 13 \\
5. & Sangat Empuk & 1 & 3 \\
\hline & $\quad$ Jumlah & 30 & 100
\end{tabular}

Sumber : Data primer diolah (2020)

Dari Tabel 5 diketahui tingkat keempukan tahu yang diproduksi oleh responden produsen tahu di Kota Mataram sebagian besar dengan tingkat cukup empuk yang diproduksi oleh 25 responden produsen atau $84 \% .4$ responden produsen tahu atau sebanyak 13\% memproduksi tahu dengan tingkat empuk, dan 1 responden produsen tahu atau sebanyak 3\% memproduksi tahu dengan tingkat sangat empuk. 
Hasil selanjutnya yaitu mengenai tingkat warna tahu yang ditawarkan oleh responden produsen tahu di Kota Mataram, 2020 dapat dilihat pada Tabel 6.

Tabel 6. Pengelompokan Tingkat Warna Tahu yang Ditawarkan Oleh Responden Produsen di Kota Mataram, 2020

\begin{tabular}{llcc}
\hline No. & \multicolumn{1}{c}{ Tingkat Warna } & Jumlah (orang) & Persentase $(\%)$ \\
\hline 1. & Sangat Tidak Putih & 0 & 0 \\
2. & Tidak Putih & 0 & 0 \\
3. & Cukup Putih & 11 & 37 \\
4. & Putih & 19 & 63 \\
5. & Sangat Putih & 0 & 0 \\
\hline & Jumlah & 30 & 100
\end{tabular}

Sumber : Data primer diolah (2020)

Dari Tabel 6 diketahui tingkat warna tahu yang diproduksi oleh responden produsen tahu di Kota Mataram sebagian besar dengan tingkat warna putih yang diproduksi oleh 19 responden produsen tahu atau 63\%. Sisanya sebanyak 11 responden produsen tahu atau sebanyak $37 \%$ memproduksi tahu dengan tingkat warna cukup putih. Tingkat warna cukup putih pada tahu yang diproduksi oleh responden produsen di Kota Mataram adalah tahu yang warnanya putih yang kekuning-kuningan.

Mengenai tingkat kesegaran tahu yang ditawarkan oleh responden produsen di Kota Mataram, 2020 dapat dilihat pada Tabel 7.

Tabel 7. Pengelompokan Tingkat Kesegaran Tahu yang Ditawarkan Oleh Responden Produsen di Kota Mataram, 2020

\begin{tabular}{llcc}
\hline No. & Tingkat Kesegaran & Jumlah (orang) & Persentase $(\%)$ \\
\hline 1. & Sangat Tidak Segar & 0 & 0 \\
2. & Tidak Segar & 0 & 0 \\
3. & Cukup Segar & 0 & 0 \\
4. & Segar & 4 & 13 \\
5. & Sangat Segar & 26 & 87 \\
\hline & $\quad$ Jumlah & 30 & 100
\end{tabular}

Sumber : Data primer diolah (2020)

Dari Tabel 7 diketahui tingkat kesegaran tahu yang diproduksi oleh responden produsen tahu di Kota Mataram sebagian besar dengan tingkat sangat segar yang diproduksi oleh 26 responden produsen tahu atau 87\%. Sisanya sebanyak 4 responden produsen atau sebanyak $13 \%$ memproduksi tahu dengan tingkat segar. Pada tingkat segar ini responden produsen memproduksi tahu yang tidak dapat terjual habis pada hari tersebut. Maka dari itu responden produsen mengolah kembali (diberlakukan khusus) tahu yang tidak terjual habis tersebut agar bisa terjual kembali keesokan harinya. 


\section{Analisis Kesesuaian Kualitas Tahu yang Diminta Oleh Responden Konsumen dan Kualitas Tahu yang Ditawarkan Oleh Responden Produsen di Kota Mataram}

Setelah mengetahui jawaban dari responden konsumen dan responden produsen di Kota Mataram mengenai kualitas tahu yang bagaimana yang diminta oleh responden konsumen dan kualitas tahu yang bagaimana yang ditawarkan oleh responden produsen, maka peneliti melihat adakah kesesuaian antara kualitas tahu yang diminta oleh responden konsumen dan kualitas tahu yang ditawarkan oleh responden produsen di Kota Mataram. Kesesuaian antara kualitas tahu yang diminta oleh responden konsumen dan kualitas tahu yang ditawarkan oleh responden produsen di Kota Mataram pada variabel keempukan, 2020 dapat dilihat pada Tabel 8.

Tabel 8. Tingkat Kesesuaian Antara Kualitas Tahu yang Diminta Oleh Responden Konsumen dan Kualitas Tahu yang Ditawarkan Oleh Responden Produsen di Kota Mataram pada Variabel Keempukan, 2020

\begin{tabular}{llrr}
\hline No. & Tingkat Keempukan & $\begin{array}{c}\text { Persentase yang Diminta } \\
(\%)\end{array}$ & $\begin{array}{c}\text { Persentase yang } \\
\text { Ditawarkan }(\%)\end{array}$ \\
\hline 1. & Sangat Tidak Empuk & 0 & 0 \\
2. & Tidak Empuk & 0 & 0 \\
3. & Cukup Empuk & 87 & 84 \\
4. & Empuk & 13 & 13 \\
5. & Sangat Empuk & 0 & 3 \\
\hline & $\quad$ Jumlah & 100 & 100 \\
\hline
\end{tabular}

Sumber : Data primer diolah (2020)

Tabel 8 merupakan tabel yang menunjukkan persentase jumlah responden konsumen yang meminta dan jumlah responden produsen yang menawarkan tahu pada setiap tingkat keempukan. Dari tabel diatas dapat dilihat persentase yang diminta oleh responden konsumen pada tingkat cukup empuk terdapat $87 \%$ dan tingkat empuk $13 \%$. Sedangkan persentase yang ditawarkan oleh responden produsen pada tingkat cukup empuk terdapat $84 \%$, empuk $13 \%$, dan sangat empuk $3 \%$.

Pada tingkat keempukan sangat empuk terdapat $3 \%$ responden produsen tahu di Kota Mataram yang memproduksi di tingkat tersebut dan $0 \%$ responden konsumen tahu di Kota Mataram meminta tahu pada tingkat keempukan tersebut. Namun menurut responden produsen tersebut tingkat keempukan tahu ini tetap ingin dikonsumsi oleh responden konsumen tahu yang berada di daerah Lombok Timur, sehingga responden produsen ini menawarkan hasil produksinya ke daerah Lombok Timur, yang diambil langsung oleh penjual-penjual tahu Lombok Timur.

Melihat keinginan responden konsumen dan penyediaan tahu oleh responden produsen maka antara keduanya sudah terdapat kesesuaian dalam hal keempukan tahu. Artinya, tahu yang diproduksi sudah sesuai empuknya dengan tahu yang diinginkan responden konsumen. Hasil penelitian menunjukkan bahwa modus data keempukan adalah 'cukup empuk' bagi responden konsumen dan responden produsen (Tabel 8). Bahkan tabel tersebut menunjukkan bahwa responden produsen tahu menyediakan tahu dengan keempukan yang lebih dari yang diharapkan responden 
konsumen tahu, yaitu ada 1 responden produsen tahu yang menyediakan tahu yang sangat empuk. Dengan demikian, keempukan tahu yang diproduksi saat ini bisa dilanjutkan untuk waktu-waktu yang akan datang.

Setelah melihat kesesuaian kualitas tahu yang diminta oleh responden konsumen dan kualitas tahu yang ditawarkan oleh responden produsen di Kota Mataram pada variabel keempukan selanjutnya akan dilihat kesesuaian kualitas tahu yang diminta oleh responden konsumen dan kualitas tahu yang ditawarkan oleh responden produsen pada variabel tingkat warna. Kesesuaian antara kualitas tahu yang diminta oleh responden konsumen dan kualitas tahu yang ditawarkan oleh responden produsen di Kota Mataram pada variabel warna, 2020 dapat dilihat pada Tabel 9.

Tabel 9. Tingkat Kesesuaian Antara Kualitas Tahu yang Diminta Oleh Responden Konsumen dan Kualitas Tahu yang Ditawarkan Oleh Responden Produsen di Kota Mataram pada Variabel Warna, 2020

\begin{tabular}{llcc}
\hline No. & Tingkat Warna & $\begin{array}{c}\text { Persentase yang Diminta } \\
(\%)\end{array}$ & $\begin{array}{c}\text { Persentase yang } \\
\text { Ditawarkan }(\%)\end{array}$ \\
\hline 1. & Sangat Tidak Putih & 0 & 0 \\
2. & Tidak Putih & 0 & 0 \\
3. & Cukup Putih & 73 & 37 \\
4. & Putih & 27 & 63 \\
5. & Sangat Putih & 0 & 0 \\
\hline & $\quad$ Jumlah & 100 & 100 \\
\hline
\end{tabular}

Sumber : Data primer diolah (2020)

Pada Tabel 9 dapat dilihat berapa jumlah responden konsumen yang meminta dan jumlah responden produsen yang menawarkan tahu pada setiap tingkat warna tahu. Dari tabel diatas dapat dilihat bahwa persentase yang diminta oleh responden konsumen pada tingkat cukup putih terdapat $73 \%$ dan pada tingkat putih $27 \%$. Sedangkan persentase yang ditawarkan oleh responden produsen pada tingkat cukup putih terdapat $37 \%$ dan pada tingkat putih $63 \%$.

Menurut saya pada warna tahu juga sudah terdapat kesesuaian. Warna juga sudah sesuai karena modus responden konsumen meminta warna 'cukup putih', tetapi produsen sudah menyediakan tahu dengan warna putih (putih lebih baik dari pada cukup putih) (Tabel 9). Tabel tersebut menunjukkan bahwa responden produsen tahu menyediakan tahu dengan warna yang lebih dari yang diharapkan responden konsumen tahu, yaitu masih banyak responden produsen tahu yang menyediakan tahu dengan warna putih. Dengan demikian, warna tahu yang diproduksi saat ini bisa dilanjutkan untuk waktu-waktu yang akan datang.

Variabel terakhir yang diteliti dalam penelitian ini untuk melihat tingkat kesesuaian antara kualitas tahu yang diminta oleh responden konsumen dan kualitas tahu yang ditawarkan oleh responden produsen di Kota Mataram adalah tingkat kesegaran pada tahu. Tingkat kesegaran merupakan faktor yang terpenting yang menjadi tolak ukur dari kualitas tahu. Kesesuaian antara kualitas tahu yang diminta oleh responden konsumen dan kualitas tahu yang ditawarkan oleh responden produsen di Kota Mataram pada variabel kesegaran, 2020 dapat dilihat pada Tabel 10. 
Tabel 10. Tingkat Kesesuaian Antara Kualitas Tahu yang Diminta Oleh Responden Konsumen dan Kualitas Tahu yang Ditawarkan Oleh Responden Produsen di Kota Mataram pada Variabel Kesegaran, 2020

\begin{tabular}{llcc}
\hline No. & Tingkat Kesegaran & $\begin{array}{c}\text { Persentase yang } \\
\text { Diminta }(\%)\end{array}$ & $\begin{array}{c}\text { Persentase yang } \\
\text { Ditawarkan }(\%)\end{array}$ \\
\hline 1. & Sangat Tidak Segar & 0 & 0 \\
2. & Tidak Segar & 0 & 0 \\
3. & Cukup Segar & 0 & 0 \\
4. & Segar & 0 & 13 \\
5. & Sangat Segar & 100 & 87 \\
\hline & $\quad$ Jumlah & 100 & 100 \\
\hline
\end{tabular}

Sumber : Data primer diolah (2020)

Dari Tabel 10 kita dapat melihat jumlah responden konsumen yang meminta dan jumlah responden produsen yang menawarkan tahu pada setiap tingkat kesegaran tahu. Dari tabel diatas dapat dilihat bahwa pada tingkat segar terdapat $13 \%$ responden produsen tahu di Kota Mataram yang memproduksi di tingkat tersebut dan 0\% responden konsumen tahu di Kota Mataram meminta tahu pada tingkat kesegaran tersebut. Karena para responden konsumen ingin selalu mengkonsumsi tahu yang baru selesai di produksi agar kandungan gizi pada tahu tersebut tidak berkurang.

Tingkat segar yang dimaksud disini adalah tahu yang sudah diolah kembali karena tidak habis terjual hari kemarinnya. Responden konsumen yang mengetahui tingkat kesegaran tahu seperti itu memilih untuk tidak jadi membeli tahu tersebut. Jika dua kali berturut-turut tahu tersebut masih tetap tidak laku maka responden produsen mengolah tahu tersebut menjadi makanan ringan.

Melihat keinginan responden konsumen dan penyediaan tahu oleh responden produsen maka antara keduanya sudah terdapat kesesuaian dalam hal kesegaran tahu. Artinya, tahu yang diproduksi sudah sesuai kesegarannya dengan tahu yang diinginkan responden konsumen. Hasil penelitian menunjukkan bahwa modus data kesegaran adalah 'sangat segar' bagi responden konsumen dan responden produsen (Tabel 10). Dari tabel tersebut terdapat $13 \%$ responden produsen perlu meningkatkan kesegaran tahunya, dengan cara memproduksi tahu dengan jumlah yang disesuaikan dengan jumlah tahu yang laku pada hari biasanya dan memproduksi tahu yang sesuai dengan keinginan konsumen, agar tidak ada tahu yang tersisa saat penjualan dan kesegaran tahu bisa tetap terjaga. 


\section{KESIMPULAN DAN SARAN}

\section{Kesimpulan}

1. Konsumen tahu di Kota Mataram meminta (mengkonsumsi) tahu dengan kualitas cukup empuk, berwarna cukup putih, dan sangat segar.

2. Produsen tahu di Kota Mataram menawarkan (memproduksi) tahu dengan kualitas cukup empuk, berwarna putih, dan sangat segar.

3. Terdapat kesesuaian antara tingkat keempukan, warna dan kesegaran tahu yang diminta oleh konsumen dan tahu yang ditawarkan oleh produsen di Kota Mataram.

\section{Saran}

Berdasarkan hasil penelitian dan kesimpulan untuk pengembangan lebih lanjut disarankan agar produsen tahu di Kota Mataram menyediakan tahu pada tingkat keempukan, warna, dan kesegaran tahu yang sesuai dengan pilihan konsumen. Hasil penelitian menunjukkan bahwa konsumen menginginkan tahu yang cukup empuk, cukup putih, dan sangat segar.

\section{DAFTAR PUSTAKA}

Dinas Perindustrian Provinsi NTB. 2015. Rekapitulasi Sentra Agroindustri Tahu di Kota Mataram. Nusa tenggara Barat. Dinas Perindustrian Provinsi NTB.

Nazir, M. 2009. Metode Penelitian. Ghalia Indonesia. Bogor.

Saragih, B. 1997. Pembangunan Sektor Agribisnis Dalam Kerangka Pembangunan Ekonomi Indonesia. Badan Perencanaan Pembangunan Nasional. Jakarta.

Sarwono, B., Saragih, Y.P. 2003. Membuat Aneka Tahu. Penebar Swadaya. Jakarta.

Soekartawi. 2002. Analisis Usahatani. Universitas Indonesia. Jakarta.

Surakhmad, W. 1989. Pengantar Penelitian Ilmiah : Dasar-Dasar Metode Teknik. Tarsito. Bandung.

Wikipedia. 2010. Pertanian Agrikultur. https://id.wikipedia.org/wiki/Pertanian. [29 September 2019].

Wikipedia. 2013. Agribisnis. https://id.wikipedia.org/wiki/Agribisnis. [29 September 2019].

Winarno, F.G. 1993. Pangan Gizi, Teknologi, dan Konsumen. PT Gramedia Pustaka Utama. Jakarta.

Yusuf, M. 2004. Dasar-Dasar Agribisnis. Universitas Mataram Press. Mataram 